\title{
The Role of Human Resource Development as a Change Agent
}

\author{
Teresia Njoki Muchira, Kellen Kiambati
}

School of Business, Karatina University, Karatina, Kenya

Email address:

terrynm2007ke@yahoo.com (T. N. Muchira)

To cite this article:

Teresia Njoki Muchira, Kellen Kiambati. The Role of Human Resource Development as a Change Agent. Education Journal. Vol. 4, No. 5, 2015, pp. 214-221. doi: 10.11648/j.edu.20150405.15

\begin{abstract}
For businesses to maintain their position in the market place or gain competitive advantage they need to change constantly. Change helps improve and increase productivity which ultimately increases sales of an enterprise. The growing global competition and the rate of technological advancement foresee a continuing need for change. An organization will require the services of a change agent to assist in in its effort to change successfully. This study examines the role of Human Resource Development (HRD) as a change agent in several areas such as organizational change management, different roles played by the change management, skills and competencies for HRD change agents, the models of change used by the change agents to facilitate change and conclusion. The study ends with recommendations for further research.
\end{abstract}

Keywords: Human Resource Development, Change Agents, Change Management, Competencies

\section{Introduction}

Currently, organizations have to keep on changing in order to remain competitive and have competitive advantage as they are operating in an environment that is fast paced and changing continuously (Biedebacha \& Spimlderholma, 2008). Improvement in employee performance can help boost the production and increase sales of an organization. Dowling and Welch (2004) postulates that growth in mergers, acquisition and alliances, organizational restructuring, global competition and rapidly changing technology are the accepted forces of change. Organizations that want to go global are likely to seek Human Resource Development (HRD) professionals for support and advice (Short and Callahan 2005). Employees are the implementers/drivers of any desired change in an organization and should therefore be involved in the planning for change. According to Ulrich and Brockband (2005) it is the responsibility of Human Resource (HR) professionals to protect the employees against the side effects of inevitable changes and to ease the effect of changes in the organizations change agents. Vital role of maximizing organization's human resource is played by the HR practitioners as it is critical for accomplishing key organizational process through the support of employee behaviour and accordingly proceed to have a successful organization.(Nel,Werner, Poisat, Sono, Du Plessis, \& Nqalo,
2011; Stone 2008; Rennie 2003; Wright \& Boswell, 2002). When the employees are involved they will own the change. HR Practitioners have been assigned many roles such as specialists in service provision, provision of guidance and advice, business partner, a strategist as well as change agent (Armstrong 2006). The change agent comes in handy because he/she facilitates this change through the personnel. $\mathrm{He} / \mathrm{she}$ is able to gain commitment from the employees. $\mathrm{He} / \mathrm{she}$ is able to facilitate change by having a potential impact on employees in all major projects (Caldwell 2003). Lunenburg (2010) in his paper Managing Change: The Role of the Change Agent only discussed general role of change agent but did not discuss the role of HRD as a change agent. This paper therefore aims at discussing the role of Human Resource Development officers as change agents.

\section{Literature Review}

\subsection{Organizational Change Management}

Hayes (2002) defines organizational change management as the transformation and modification of whole organizations, or parts, in an effort to maintain or improve upon the effectiveness in productivity, revenue, market competitiveness and internal alignment. Kotter J., (2011) indicates that change management is an approach to transitioning individuals, teams and organizations to a 
desired future state. He continues and posits that change management is the utilization of basic structures and tools to control any organizational change effort. It is an organizational process aimed at helping employees to accept and embrace changes in their current business environment as they are the lifeblood of a company according to (Du Plessis., 2009 \& Rennie, 2003)

According to Nel, P. S., Werner, A., Poisat, P., Sono, T., Du Plessis, A. J. \& Nqalo, O. (2011), the environment of the $21^{\text {st }}$ century is turbulent and uncertain and organizations which manage change effectively by continuously adapting their systems, strategies, cultures, products and bureaucracies are branded as masters of renewal. Guy, Beaman and Weinstein (2005) affirms that the century is moving forward at a rapid pace; people are becoming more technologically advanced, have higher expectations, open to globalization and growing more innovative with each passing day. Carnall (2003) portrays organizations that change as value adding companies due to their consistently emerging needs to keep up with customers' needs. He continues to say business should continuously reframe their strategies, corporate culture, technologies, training and deployment and their leadership or leadership styles to remain relevant. Purcell (2001) submitted that HR can play a most important part in change as Human Resource Management strategies are concerned with the future, the unknown, thinking of and learning how to do things differently, performing things differently and handling its implementation. Organizations that have integrated their human resource management policies with the strategies and the strategic change process, training, and employee relations manage their change successfully (Armstrong, 2006)

According to Jamrog and Overhold, (2004) HR Practitioners in past have been tagged as administrators but firms wants HR function to go beyond the delivery of cost effective administrative and provide expertise on how to leverage human capital. According to Rennie, 2003; Walker and Stopper, (2000) considerable attention to HR practitioners' roles as business partners and leader of change has also been received. Hobeche, (2006) posits that over the years the function of HR has become more multifaceted as the pace of change quickens, requiring a transition toward more value-added roles such as the role of change agent. Nel et al., (2011) says that HRD practitioners have critical role to play to ensure that the change process runs smoothly as change in itself causes a high level of turmoil on organizations.

\subsection{Models of Change}

The change agents can institute change by following Kurt Lawin's three steps change model and Kotters eight steps model.

Normandin (2012) in his article "Three Types of Change Management Models" explain Kurt Lewis's Model of change as follows: Kurt Lewin created this change models in 1950s where he observed that people desired to operate in comfort zone. According to George and Jones, (2002), a three-step process for successful organizational change was proposed which are unfreezing, moving, and freezing.

\subsection{Unfreeze}

To avoid resistance to change the first stage of change involves preparing the organization to accept that change is necessary, which involves breaking down the existing status quo before you can build up a new way of operating. Schein, (1992 indicates that employees are motivated to unfreeze when they understand the crisis the firm is going through or have a good vision to motivate them. Breaking down of the status quo is the unfreezing Burns, (2004) indicates. The preferred environment should be created for change to occur so the new ideas and visions can be formed in people's mind.

The unfreezing process passes through three phases. Firstly there must be indicators that current conditions are not ideal. Secondly, this vital information must be communicated to organizational members and finally a solution has to be found to reduce members of anxiety. This first phase of change is the most difficult and stressful. A period of thawing or unfreezing must be initiated through motivation.

\subsection{Transition/Change}

In this stage, people have resolved their uncertainty and are looking forward to new ways of doing things and support the new direction. Morrison, (2010) points out that since change is dynamic it will doubtless involve a transition period if it will be effective. He continues to say that change can start when members open their minds. The second phase enables members to move from a less acceptable situation to the desired future as it is more interactive Barnstable (2012). For the process to be successful, reassurance from leadership is required. Also communication is vital for the success of change and people need to be given time to understand the change and feel highly connected to the organization throughout the transition period.

\subsection{Refreeze}

At the point when the progressions are coming to fruition and individuals have grasped the better approaches for working, the association is prepared to refreeze. Ramos (2011) indicates that changes in the association are completely acknowledged by all parts and the principle reason at this stage is strength. The outward indications of the refreeze are a stable association outline, reliable sets of responsibilities, etc. The refreeze arrange likewise needs to help individuals and the association disguise or organize the progressions. This implies verifying that the progressions are utilized constantly; and that they are fused into regular business. With another feeling of steadiness, workers feel sure and agreeable with the better approaches for working.

\subsection{Kotter's 8 Step Change Model}

According to Kotter and Cohen (2002) there are eight critical steps an organization needs to go through for 
successful change.

Leaders who successfully transform businesses do eight things right and they do them in the right order! (John Kotter)

\subsubsection{Create a Sense of Urgency}

People will act immediately if they are convinced and see the need for change. The first step in successful change effort is to make sure sufficient people act with sufficient urgency. For change agents to have power and credibility to initiate the required change program the need for change must be understood(Kotter, 1997) The use of consultants as a tactic for creating sense of urgent and to challenge the status quo is recommended by Kotter (1996). This is also applied to examining the realities, identifying and discussion crisis, potential crises or major opportunities.

\subsubsection{Creating the Guiding Coalition}

Appelbaum.S.H., Habashy S. Jean-Luc Malo S.J, Hisham S. (2012) in their Journal "Back to the future: revisiting Kotter's 1996 change model", cites Kotter (1996) and posits that no one person is capable of single-handedly leading and managing the change process in an organization and putting together the right "guiding coalition" of people to lead a change initiative is critical to its success. Therefore, it is critical for the change operators to assemble a gathering with enough power to lead the change and get the gathering to cooperate like a group. A compelling controlling gathering has two qualities. It's comprised of the right individuals, and it exhibits cooperation. The "right individuals" are those people with suitable abilities, administration limit, authoritative validity, and the associations with handle hierarchical change like the change specialists. According to Kotter (1996), the introductory undertaking of the controlling coalition is to define a dream for the change exertion and to guarantee that it is conveyed all throughout the association.

\subsubsection{Developing a Vision and Strategy}

According to Kotter, (1996) employees are able to understand and to act on a vision if it clearly defined. A good change agent should help the organization to ask themselves these questions; What change is necessary? What is our vision for the new organization? What should not be altered? What is the best way to make the vision a reality? What change strategies and unacceptably dangerous? If they are able to answer these questions they can transit change very well. Managers who understand the change effort are more likely to be excited about the change and less likely to think that change effort would fail (Washington \& Hacker 2005).

\subsubsection{Communicating the Change Vision}

Communication is very vital for any organization in all aspects. According to Bordia et al, (2004) communication is a critical element of the organizational change process as it can reduce uncertainty, decrease ambiguity and even affect the type of positive or negative response to the change. (Nelissen and Van Selm, 2008). The vision should be understood and accepted by as many people as possible. Change messages communicated should be simple not complex for easy comprehension.

\subsubsection{Empowering Broad-Based Action}

According to Kotter (2002) Barriers should be eradicated when people begin to understand and act on a change vision. Structures and obstacles that undermine the vision should be removed and systems changed.

\subsubsection{Generating Short-Term Wins}

Appelbaum. et al (2012) cites Pietersen, 2002) in which The former President of Lever Brothers' Foods Division in the USA, Willie Pietersen, says that large-scale change can be a long, formidable undertaking, so it is important to create short-term wins. Achievements that can easily be visible should be planned. Short term wins should be recognized and those employees involved should be rewarded.

\subsubsection{Consolidating Gains and Producing More Change/Don't Let Up}

Determination and persistence should be nurtured and encouraged by use of increased credibility to change structures, systems and policies. According to Pfeifer et al. (2005) the main goal for gathering first successes is verifying the credibility of vision and strategy through the use of measurable results. He continues and says that these first successes will be required to plan for further change.

\subsubsection{Anchoring New Approaches in the Culture}

Change agents require a support structure for sustainability of change. The structure should offer training and mentoring. Communication and recognition of change initiatives should be used like newsletters, informal meetings seminars, web sites among others (Massey \& Williams, 2006). Articulate the connections between the new behaviors and organizational success, and develop the means to ensure leadership development and succession.

\subsection{Change Agent Role}

Lunenburg (2010) posits that there are three distinct roles of any change agent; consulting role where the agent assists employees to generate data from within the firm or from external sources, and through analysis of valid data helps the workers to solve problems. Training role in which the agent trains organizational members to learn new methods by providing them with new skills. Research role where he/she may not only train employees but design an evaluation component that can be used in solving not only the current problem but also solve future problems (Carnall, 2008; Dawson, 2010; Stephen, 2010; Tidd, 2010).

\subsection{The Human Resource Development Change Agent's Role}

Change agents are the persons who initiate change and manage change in the organizations. They are specialized in theory and practice of managing changes (Varghese et al 2012). According to Lawler and Boudreau, (2009) the HRD can support the introduction of new technology through staff training of the operations of the new technology. A 
person responsible for organizing and coordinating the overall change effort can be a change agent according to Carter McNamara (2005). He/she can either be an internal change agent who is frequently a sub set for organizational leaders or an external change agent, who are most likely to be consultants or managers brought in to invoke change. (Blewett 2000). The role of HRD as change agent might fail if it does not strongly define the process and priorities of change effort as the role of HR in driving changes varies among different organizations. (Kesler, 2000)

Holbeche, (2008) argues that during recruitment of staff when an organization needs to employ new employees, the HR should be able to help this task to proceed smoothly without a hitch. This is because they are able to hold the tasks related to change. Customer needs and expectations are also evaluated. This is used to evaluate the business satisfaction to the customers.

The role played by the HRD professional has equally changed with the change in the organizational environment. Gilley, Quatro, Lynham, (2003) articulates that in the past the prime responsibility of HRD professionals was to identify, select and evaluate training programmes which could be external or internal and deal with the performance of the employees through designing or customizing training intercessions (Gilley el al., 2003). Therefore, training intervention was the main focus of HRD (Gilley, el al., 2003). However, at present the HRD Professionals acts as Strategic adviser to help the decision makers on issues related with HRD. (Du Plessis., 2009; Rennie, 2003; Walker \& Stopper,2000). They also play the role of an HR systems designer and developer by assisting the HR management in designing and developing HR systems in an organization to increase its performance (Rennie., 2003; Walker \& Stopper., 2000) They also act as organizational change agents by helping the management in designing and implementing change strategies to transform the organization (KJ Singh 2013). Ulrich and Brockbank (2005) advances that HR practitioners comprises both strategic partner and change agent roles and therefore according to Caldwell, (2003) HRD Professionals may performance a proactive role in change management as they are in a good position. According to Green (2001) HRD professionals are uniquely positioned to take responsibility for this role in the organization as it deals with the culture of a firm. According to (CIPD, 2005, Ulrich, 2005; Kenton \& Yarnall, 2005; McLagan, 1996; Nijhof, 2004; Tjepkema et al., 2000) HRD roles have been transformed to strategic business partner, internal consultant and change agent which is the main focus for this study.

\section{The Human Resource Development Specialist as Change Agent}

Armstrong, (2006) cites Caldwell (2001) who categories Human Resource Development change agents in four dimensions which are transformational, incremental, Human
Resource vision and Human Resource expertise. Transformational change is a major change that has a dramatic effect on HR policy and practice across the whole organization. Incremental change is gradual adjustments of Human Resource policy and practices that affect single activities or multiple functions. HR vision is a set of values and beliefs that affirm the legitimacy of the Human Resource function as strategic business partner. Human Resource Development expertise is the knowledge and skills that define the unique contribution the Human Resource professional can make to effective people management (Caldwell, 2001).Caldwell goes on to suggest that the change agent roles that can be carried out by Human Resource Development professional are change champions, change adapters, change consultants and change synergists. Caldwell (2003) describes these roles as follows

\subsection{Change Champions}

Align Human Resource with the business strategy and provide "sponsorship for strategic change" Proactive and persuasive. Have credibility (which is directly linked to business experience), Possess analytical skills (e.g. gap analysis) and political skills (to make change happen) Take risks, inspire people and make them aware of the need for change (Caldwell, 2003).

\subsection{Change Adapters}

HR generalists who implement the change in business units and functional areas "Translate the vision into practical actions" and are involved in the implementation process. Need to encourage, persuade, empower \& challenge the line. (Armstrong, 2006).

\subsection{Change Consultants}

According to Carnall, 2008; Dawson, 2010; Stephen, 2010; Tidd, (2010), as Consultant the change agent assists the workers to generate data from within and outside the organization. Caldwell (2003) on the other hand posits that work on a project or specific stages of an HR project need specialized knowledge or technical expertise, administrative skills, consulting skills, project management experience \& skills as well as the "ability to meet demanding timescales".

\subsection{Change Synergists}

The activities concerned in co-operating the effort that mutually support the success and involvement of diverse resources energies and people is referred to as synergy (Barnstable, 2012). Caldwell (2003) indicated that Human Resource Development change agents are capable of strategically coordinating, integrating and delivering complex, large scale and multiple change projects across the whole organization. Need coordination, integration, project management and leadership competencies operate strategically and act as catalysts for change. 


\subsection{Importance/Reasons of Organizational Changes}

Change is important for any organization because, without change, businesses would likely lose their competitive edge and fail to meet the needs of what most hope to be a growing base of loyal customers (Richard L.2011). It is important because business is an ongoing process of change like everything else. Organizational changes can occur as a response to current crisis situation or as a reaction to an ever changing environment. A progressive and proactive manager can also trigger change. Transfer of executive power in organization can also trigger organizational change (Haveman, Russo \& Meyer, 2001).

According to Swaim R. (2011) different reasons which can be proactive or reactive can make organizations to change which include and not limited to:

\subsection{New Technology}

Technology is changing rapidly and it is prudent for organization to identify new technology and more efficient and economical methods to perform work to have competitive advantage. Technological innovation has created the need for change in organizations (D'Agustino, 2011). According to Francis (2010) organizations have to adopt new technology to be cost effective and have competitive advantage. Though there is disruption at first due to adoption of new technology, the change ultimately leads to increased productivity and service (Swaim, 2011).

\subsection{Mergers \& Acquisitions}

Mergers and acquisitions create change in a number of areas often negatively impacting employees when two organizations are merged and employees in dual functions are made redundant. Some expenses are cut while some resources are reallocated to the production of new products or services (Swaim, 2011).

\subsection{Reaction to Internal \& External Pressure}

Internal pressure comes from management and employees, particularly those in organized unions often exert pressure for change. On the other hand external pressures come from many areas, including customers, competition, changing government regulations, shareholders, financial markets, and other factors in the organization's external environment Lunenburg (2010). Globalization is another aspect that makes organization change.

\subsection{Economic Changes}

Brimley and Garfield, (2009) posits that the attitudes and morale of employees suffer during period of inflation and recession as affected by economic changes which can ultimately affect organizational performance.

\subsection{Government Laws and Regulations}

Change can occur due to change in government laws and regulations. For instance the equal employment opportunity and the $3^{\text {rd }}$ rule (Constitution of Kenya 2010) must be enforced (Robinson, 2010).

\subsection{Customer Needs}

Customers' needs and preferences keep on changing For example customers who were satisfied with conventional ovens many years ago are sometimes impatient with the microwave today. As the world evolves, customer needs change and grow, creating new demand for new types of products and services and opening up new areas of opportunity for companies to meet those needs (Swaim R. 2011).

\subsection{Skills and Competencies Required For Human Resource Development Change Agents}

The ability to add value to business is referred to as Competency; to achieve sustainable competitive advantage competence must focus on the process leading to changing business conditions. Ulrich et.al (2008) Competence indicates sufficiency of knowledge and skills that enable someone to act in a wide variety of situations (Business dictionary) Choi Sang Long (2013) lists the following as the competencies for HR professional as change agents:Effective relationship skill, Human resource development (HRD) skill, Performance management, Value chain knowledge, and Conflict management.

\subsection{Effective Relationship Skill}

The ability to add value to business is referred to as competency according to Ulrich et.al (2008). To achieve sustainable competitive advantage, the agents must focus on changing business conditions and help lead the process of change using their competencies.

\subsection{Professional Competency}

Long and Ismail, (2008) asserts that professional competencies are allied to employee champion and administrative expert roles which entail credibility of the agent. As HR professionals or line managers, their credibility should be gained by their working partners as employee champions. One the other hand they should be able to deliver traditional operation HR activities in their business (Long \& Ismail, 2008) restructuring, talent and performance management, providing advice and support on career and organizational development, evaluating the HR practices and programs' impact could be included in these activities.

\section{Human Resource Development (HRD) Skill}

According to Ketter (2006) Human Resource Development professional need to create an enabling environment for learning and comprehend the process of learning as change agents. Employees are helped by Human Resource Development skills to improve organizational and 
personal knowledge, skills and abilities.

\subsection{Performance Management}

HR Practitioners as change agents need to forewarn employees to improve work performance and productivity. Glendinning (2002) defines performance management as a process that unites goal setting, development and performance appraisal not a single, common system whose purpose is to ensure that the firm's strategic objectives are supported by employees. Dessler (2008) affirms that this competency is paramount to $\mathrm{HR}$ agents to guarantee employees' performance is measured with proper instruments and tools.

\subsection{The Right Attitude}

Change is a complex and labour-intensive process that arouses feelings and emotions and therefore change cannot succeed with great persistence (Tan \& Kaufmann 2010). Without the right attitude managers cannot lead the team through difficulties and challenges of frustrated teammates, angry people unforeseen problems among others with stamina and great determination.

\subsection{The Necessary Skills}

Varieties of skills are compulsory for change agent to succeed. For example conflict management and managing challenges of transition. They should also possess the ability to remain highly effective under extreme pressure. Analytical skills are also needed which Balogun and Hailey, (2005) indicates that they assist the change agent in analyzing complicated situation in the firm and also helps them to be flexible enough to work around roadblocks and handle upcoming issues. People skills are a must as the change involves staff and this will be able to forte strong interpersonal relationship and communicate with different groups to create readiness for change (Balogun \& Hailey 2005). The change agent needs to raise understanding for the need to change by creating dissatisfaction with the status quo (Gerlick's, 1991; Armenakis et al., 1993; Raineri, 2008). Good listening skills are a necessity to help them to empathize and also have good listening skills. According to Becker et al., (2001) increased perception of effectiveness of Human Resource Development change agents is contributed by their credibility. On the other hand Long \& Ismail (2008) stresses the foundation for Human Resource Development professional is his/her personal credibility skills which assist in dealing with employees during change process. Last but not least communication skills are a must as communication is the glue that keeps the organization together and helps to move to the desired future. They need to communicate effectively and efficiently at all levels of the entire organization (Tan \& Kaufmann, 2010).

\subsection{Types of HRD Change Agents}

Nameer (2008) describes change agents as external change agents, internal change agents and external-internal change agents. External agents are outside consultants temporally employed to oversee the change process. The external agents are usually needed when the changes are of complex nature with limited capacity or capability within and when there is need for an external intervention by people with no conflicts of interest, prejudice or loyalty (Green 2012). Internal change agents are persons employed by the firm who knows its problems and has the capability of improving or fixing the problem.(Nemeer,2008) The internal agents are deployed when there is an internal driver to use or rely upon internal capacity or capability or when there is belief that owners should clearly be internal(Green, 2012). According to Nameer(2008) on the other hand external-internal change agents are persons or small group within the firm designated to work with the external change agents so that intervention could be implemented effectively with their help.

\section{Conclusion}

Large or small firms need change agents when they want to change either their structure, introduce new products/services or new technology. A change agent helps an organization to transits to the new way of doing things and we can therefore say that a change agent is any person with power and skills to facilitate and guide change effort. Change agents can either be external or internal who plays different roles such as change champions, change adopters, consultant and synergists. They are able to propel change through different change models which are adopted by the organizations. When HRD plays the role of change agent, they are able to successfully manage the change because the HR knows how to deal with the human resource who are organizational valuable assets and who are the movers of change.

\section{Recommendations for Further Research}

The current seminar paper focused on the Role of Human Resource Development as a change agent. Future research should focus on the role of advanced human resource development as a change agent and every trends affecting HRD as change agents. The author recommends that future studies should look into how human resource development can be tailored for a diverse workforce. There exists scanty literature on human resource development in Kenya; more studies should therefore be carried out.

\section{References}

[1] Armenakis, A. A., Harris, S. G., \& Mossholder, K. W. (1993). Creating Readiness for Organizational Change. Human relations: studies towards the integration of the social sciences, $46(6), 681$. 
[2] Armenakis, A.A. and Harris, S.G. (2009), "Reflections: our journey in organizational change research and practice", Journal of Change Management, Vol. 9 No. 2, pp. 127-42.

[3] Armstrong M Human Resource Management Practice $\left(10^{\text {th }}\right.$ Ed $)$ London\& Philadelphia, Kogan Page Ltd. Pg71-76(2006)

[4] Balogun, J., \& Hailey, V. H. (2008). Exploring strategic change. Edinburg Gate: Pearson Education Limited.

[5] Barnstable A., (2012). Organizational Change Management: What is the process for? Implementing organizational change? Retrieved on $8 / 7 / 2014$

[6] Becker, E., Huselid, M. A. \& Ulrich, D. (2001). The HR Scorecard: Linking people, strategy, and performance. Boston, MA: Harvard Business School Press.

[7] Biedenbacha, T. and Soumlderholma, A. (2008), "The challenge of organizing change in Hypercompetitive industries: a literature review", Journal of Change Management, Vol. 8 No. 2, pp. 123-45.

[8] Blewett V.L.,(August, 2000), Workers Changing Work: The Influence of Worker Power

[9] Bordia, P., Hunt, E., Paulsen, N., Tourish, D. and DiFonzo, N. (2004), "Uncertainty during organizational change: is it all about control?", European Journal of Work and Organizational Psychology, Vol. 13 No. 3, pp. 345-65.

[10] Brimley, V., \& Garfield, R. R. (2009). Financing education in a climate of change $\left(10^{\text {th }}\right.$ ed.). Boston, MA: Allyn \& Bacon.

[11] Buchanan, D., Fitzgerald, L., Ketley, D., Gollop, R., Jones, J.L. and Saint Lamont, S. (2005), "No going back: a review of the literature on sustaining organizational change", International Journal of Management Reviews, Vol. 7 No. 3, pp. 189-205.

[12] Burns, B 2004.Kurt Lewin and the Planned Approach to Change: A Re-appraisal Journal of Management Studies,41:6, September 2004,0022-2380, retrieved on $8 / 7 / 2014$

[13] Burke, W. W. (2011). Organizational change: Theory and practice. Thousand Oaks, CA: Sage.

[14] Caldwell, Raymond (2003)The changing roles of personnel managers. Old Ambiguities, New Uncertainties. Journal of Management Studies 40 (4), pp. 983-1004. ISSN 0022-2380.

[15] Caldwell，R (2001) Champions, adapters, consultants and synergists: the new change Agents in HRM, Human Resource Management Journal, 11(3), pp 39-52

[16] Carnall, C. A. The Change Management Toolkit. London: Thomson, 2003. Bibliography.

[17] Carnall, C. A. (2008). Managing change in organizations. Upper Saddle River, NJ: Prentice Hall.

[18] Carter McNamara (2005), Field Guide to Consulting and Organizational Development.

[19] Constitution of Kenya 2010

[20] D'Augustino, S. (2011). Adaptation, resistance, and access to instructional technologies: Assessing future trends in education. Hersey, PA: IGI Global. Dawson, P. M. B. (2010). Managing change, creativity and innovation. Thousand Oaks, CA: Sage. Retrieved on 26/06/2014.
[21] Dessler G. Human Resource Management, 11th ed., Upper Saddle River, NJ: Prentice Hall International, 2008. Retrieved on $25 / 06 / 2014$

[22] Divya Varghese, Jai Jasmine, Neelam, NehaMarwah (Neha Raj(2012).HRD as a Change Agent

[23] Dowling, P.J. \& Welch, D.E. (2004). International Human Resource Management: Managing people in a multinational context (4 ed.). United Kingdom: Thomson.

[24] Du Plessis, A.J. 2009. An overview of the influence of globalization and internationalization on domestic Human Resource Management in New Zealand. International Review of Business Research Papers 5(2), March: 1-18.

[25] D. Ulrich and W. Brockbank, The HR Value Proposition, Boston, MA: Harvard Business School Press, 2005. Retrieved on $11 / 6 / 2014$

[26] D. Ulrich, W. Brockbank, D. Johnson, K. Sandholtz, and J. Younger, $H R$ Competencies: Master at the Intersection of People and Business, The RBL Institute, The Society for HRM, 2008.

[27] Francis A., (2010) Factors Affecting Organizational Change. Retrieved on $8 / 7 / 2014$

[28] Gilley, J. W., Quatro, S., A., \&Lynham, S. A. (2003). Strategic HRD and Its Transformation. In A. Maycunich Gilley \& J. Callahan, L. \& L. Bierema, L. (Eds.), Critical Issues in HRD: A New Agenda for the Twenty-First Century (pp. 23-48). Cambridge, MA: Perseus Books Group.

[29] George, J. M., \& Jones, G.. R. (2002). Understanding and Managing Organizational Behavior(3rd). New York: Pearson Education, Inc

[30] Green M.(2012) Internal or External Change Agents? Retrieved on $27 / 6 / 2014$

[31] Greene, R.J. (2001). Effectively Managing Intellectual Capital: Critical Challenge for Human Resources. SHRM WhitePapers.

[32] Glendinning P "Performance management: Pariah or messiah," Public Personnel Management.vol. 31, no. 2, pp. 161-178, 2002 retrieved on $25 / 06 / 2014$

[33] Guy, Gregory R, Karen V. Beaman, and Carole Weinstein.Effecting Change in Business Enterprises Current Trends in Change Management. New York, NY: Conference Board, 2005. Bibliography. Retrieved on 12/6/2014

[34] Haveman, H. A., Russo, M. V., \& Meyer, A. D. (2001). Organizational environments in Flux: the impact for regulatory punctuations on organizational domains, CEO succession, and performance. Organization Science, 12, 253273.

[35] Hayes, John. The Theory and Practice of Change Management. New York: Palgrave, 2002. Bibliography

[36] Holbeche, L., (2008). Aligning Human Resources and Business Strategy. 2nd ed. New Jersey: ButterworthHeinemann.

[37] Holbeche, L. 2006. Understanding change: Theory, implementation and success. Great Britain: MPG Books Ltd. Retrieved on 12/6/2014 
[38] Jamrog, J.J., \& Overholt, M.H 2004. Building a strategic HR Function: Continuing the Evolution. Human Resource Planning, 27(1), 51-62.

[39] Kesler, Gregory. (2000). Four steps to building an HR agenda for growth: HR strategy revisited. HR. Human Resource Planning. Tempe 2000. 23(3), 24-37.Kesler, G. and Law, J. (1997). "Implementing Major Change in The HR Organization: The Lessons Of Five Companies." Human Resource Planning,20(4), 26-38.

[40] Ketter, P (2006) "Investing in learning: Looking for performance," Training \& Development, vol. 60, No. 12, pp. 30-33,

[41] Kotter, J.P. (1996), Leading Change, Harvard Business School Press, Boston, MA.

[42] Kotter, J.P. (1997), Chaos, Wandel, Fu"hrung - Leading Change, ECON, Dü sseldorf.

[43] Kotter,J(2011) Change Management vs. Change Leadership What's the difference?

[44] Kotter J. and Cohen D. Kotter J(2002) The Heart of Change: Soundview Executive Book Summaries, P.O. Box 1053, Concordville, Pennsylvania 19331 USA

[45] Long, C. S., \& Ismail W. K. (2008). Understanding the relationship of HR Competencies \&Roles of Malaysian Human Resource Professionals. European Journal of Social Sciences, 7 (1), 88-103.

[46] Lunenburg F.C.(2010) Managing Change: The Role of the Change Agent: International Journal of Management, Business, and Administration Volume 13, Number 1

[47] Lunenburg F.C.(2010) Forces for and Resistance to Organizational Change: National Forum of Educational Administration and Supervision Journal Volume 27, Number 4, 2010 Retrieved on 8/7/2014

[48] Nameer(2008) Change Agent Who in organizations is responsible for managing planned Change activities? Retrieved on $27 / 6 / 2014$

[49] Massey, L. and Williams, S. (2006), "Implementing change: the perspective of NHS change agents", Leadership \& Organization Development Journal, Vol. 27 No. 8, pp. 667-81.

[50] Nelissen, P. and van Selm, M. (2008), "Surviving organizational change: how management communication helps balance mixed feelings", Corporate Communications: An International Journal, Vol. 13 No. 3, pp. 306-18.

[51] Morison, M 2010 Kurt Lewin three step model change theory, retrieved on $8 / 7 / 2014$

[52] Nel, P. S., Werner, A., Poisat, P., Sono, T., Du Plessis, A. J. \&
Nqalo, O. 2011. Human Resources Management (8th ed.). South Africa: Oxford University Press.

[53] Pfeifer, T., Schmitt, R. and Voigt, T. (2005), "Managing change: quality-oriented design of strategic change processes", The TQM Magazine, Vol. 17 No. 4, pp. 297-308.

[54] Purcell, J (2001) The meaning of strategy in human resource management, in Human Resource Management: A critical text, second ed J Storey, Thompson Learning, London. Normandin B. (2012) "Three Types of Change Management Models" Retrieved on 30/6/2014 Ramos J.,L.,(2011) Change Management Lewis 3 Step Model of Change Rennie, W.H.2003. The Role of Human Resource Management and the Human Resource Professional in the New Economy. University of Pretoria, Pretoria.

[55] Ritchie. B 2006, Mind tools Newsletter - Retrieved on 8/7/2014 Richard Leigh Why Is Change Important in an Organization? Retrieved on 11/6/2014 Robinson, R. (2010). Employment regulations in the workplace: Basic compliance for Managers. New York, NY: M. E. Sharpe. Short, D., C., \& Callahan, J., L. (2005). 'Would I Work for a Global Corporation?' And Other Ethical Questions for HRD. Human Resource Development International, 8(1), 121-125. Retried on 11/2/2014 Singh K.J. (2013) What is role of HRD Professional? Retrieved on 13/6/2014

[56] Steven H. Appelbaum, Sally Habashy, Jean-Luc Malo, Hisham Shafiq, (2012),"Back to the future: revisiting Kotter's 1996 change model", Journal of Management Development, Vol. 31 Iss: 8 pp. $764-782$

[57] Storey, J. (1992). Developments in the Management of Human Resources. Oxford: Blackwell Publishing. Swaim R(2011)Nine Reasons Organizations Need To Change Retrieved on 18/6/2014 Tan A. \& Kaufmann (2010) Making Good Change Agents: Attitude, Knowledge, Skills. Retrieved on $25 / 06 / 2014$

[58] Thota, H. (2012). Key concepts in innovation. New York, NY: Palgrave Macmillan.

[59] Tidd, J. (2010). Managing innovation: Integrating technology, market and organizational change. New York, NY: Wiley.

[60] Ulrich, D., \& Beatty, D. (2001). From Partners to Players: Extending the HR Playing Field. Human Resource Management, 40(4), 293-307.

[61] Ulrich, D., \& Brockbank, W. (2005). The HR Value Proposition. Boston, MA: Harvard Business School.

[62] Walker, J. W., \& Stopper, W. G. 2000. Developing human resource leaders. Human Resource Planning, 23(1), 38-44. Washington, M. and Hacker, M. (2005), "Why change fails: knowledge counts", Leadership \& Organization Development Journal, Vol. 26 No. 5, pp. 400-11. 